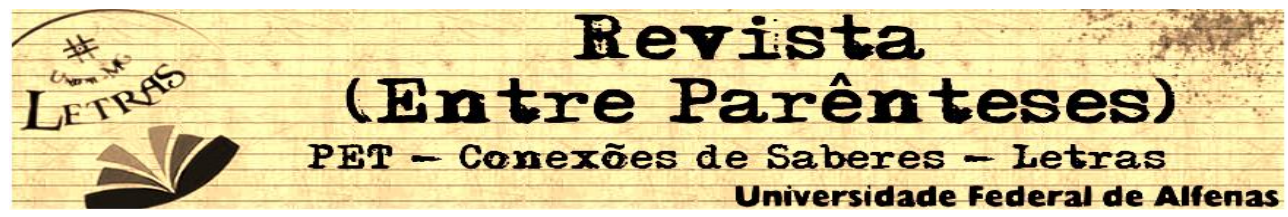

\title{
Aspectos universais em estruturas linguísticas: um estudo com base em parâmetros culturais
}

\author{
José Luiz Moreira Junior ${ }^{1}$ \\ Universidade Federal de Alfenas \\ Jr.sephiroth@hotmail.com \\ Celso Ferrarezi Junior² \\ Universidade Federal de Alfenas \\ cferrarezij@superig.com.br
}

\begin{abstract}
Resumo: Diversos estudos linguísticos apresentam um panorama satisfatório da formação da maioria das línguas que existem no mundo e as diferenças entre si nos seus níveis linguísticos. Apesar dessas diferenças, é possível perceber alguns aspectos universais entre elas, que parecem atestar uma relação corpo-cultura-língua, possibilitando assim, aplicar uma visão multidirecional sobre a linguagem. A concepção gerativa de Chomsky aliada à cultura das sociedades e a algumas deficiências em genes como o FOXP2 nos dão informações que apontam para o fato de que os aspectos universais entre as línguas têm uma certa função que atende também a características biológicas ligadas, por exemplo, à sobrevivência.
\end{abstract}

Palavras-chave: 1. Relação língua/cultura. 2. Foxp2. 3. Língua. 4. Semântica. 5. Universais linguísticos

Abstract: Several linguistic studies present a satisfactory overview of the formation of most of the languages that exist in the world and the differences between them in their linguistic levels. Despite of these differences, it is possible to notice some universal aspects between them, which seem to attest body-language-culture relations. This relations enables applying a multidirectional view on language. The generative conception of Chomsky allied to society culture and to some deficiencies in genes such as FOXP2 give us information that points to the fact that the universal aspects of languages have a certain function that also calls to biological traits such as, for example, survival.

Keyworks: 1. Language vs. culture relations. 2. Foxp2. 3. Language. 4. Semantics. 5. Linguistic universals

\section{Introdução}

Muitas pessoas são capazes de perceber, sem muito esforço, como uma língua é diferente da outra. Porém, ao adentrarmos nessas diferenças, o que se pode observar é um afunilamento rumo a certos padrões orgânicos comuns a todas

\footnotetext{
${ }^{1}$ Graduando em letras. Membro do Grupo de Pesquisas Linguísticas Descritivas, Teóricas e Aplicadas - UNIFAL/MG.

2 Professor Dr. Celso Ferrarezi Junior. Docente do Instituto de Ciências Humanas e Letras e líder do Grupo de Pesquisas Linguísticas Descritivas, Teóricas e Aplicadas - UNIFAL/MG 


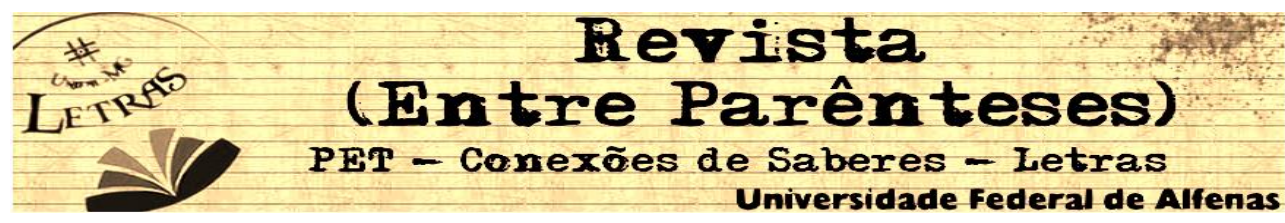

elas. É, em alguns desses padrões universais, como os nomes, a predicação e as analogias, que podemos perceber que tais peculiaridades universais podem estar intimamente ligadas a padrões biológicos de linguagem.

A relação língua-mente tem sido estudada durante séculos e segue um caminho não muito claro devido à complexidade que envolve uma língua desde sua natureza semântica até os genes responsáveis, em parte, pelo funcionamento linguístico. Os estudos sobre essa relação são fundamentais para uma compreensão mais profunda do funcionamento da linguagem, o que possibilitaria uma compreensão mais detalhada de doenças como dislexia e afasia.

Este trabalho tem como objetivo analisar a natureza de atos comuns como nomear e criar analogias apresentados em todas as línguas descritas do mundo colocando-os em correlação com aspectos culturais e biológicos que envolvem a linguagem, os compreendendo em sua grande maioria como interdependentes.

A teoria que norteou este trabalho foi a semântica cultural e sua escolha justificou-se pelo fato de que esta parece ser a única teoria disponível que dá conta, ao mesmo tempo, dos aspectos semântico-estruturais da língua e dos aspectos culturais como uma continuidade indissociável. Tal peculiaridade permite, ao estudioso, adentrar os aspectos abordados na presente pesquisa diferenciando o que é linguístico-cultural do que parece ser linguístico-biológico e universal. Nessa linha de trabalho, conseguimos contrapor aspectos de uma língua natural que antes eram tidos como meramente sistêmicos e propor uma análise multidimensional dos dados estudados.

\section{A questão dos universais linguísticos e sua relação com a cultura}

O primeiro pressuposto é baseado em Chomsky, segundo o qual "há uma faculdade da linguagem, ou seja, há uma parte da mente/cérebro que é dedicada ao conhecimento e ao uso da linguagem." (CHOMSKY, 2008, p. 18). Com base nessa perspectiva poderemos situar a linguagem, em um estado inicial, em um campo biológico que parece atestar padrões que são manifestados no campo extrabiológico e que, ao mesmo tempo, evidenciam uma inter-relação entre corpo e cultura. 


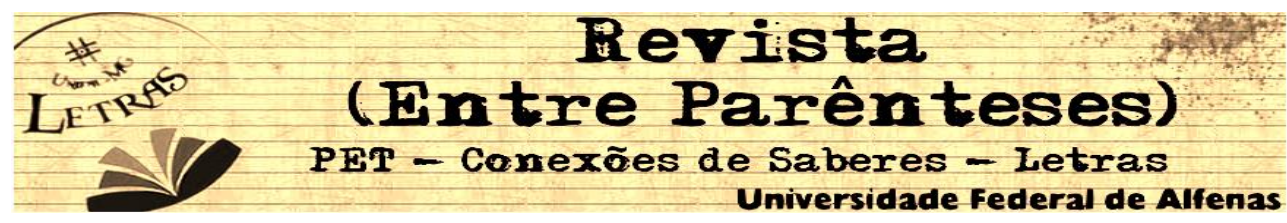

A concepção de Chomsky sobre o estado inicial da faculdade da linguagem ganha extrema lógica se observarmos a diversidade cultural. Segundo Chomsky (2008, p. 6), podemos pensar o estado inicial da linguagem como "[...] uma rede de fios fixa conectada a um painel com interruptores; a rede de fios é constituída pelos princípios da linguagem e os interruptores são as opções a serem determinadas pela experiência.". As quase infinitas opções oferecidas pelos "interruptores" geram os parâmetros de cada língua natural específica. Caberia verificar quem ou o que aciona esses interruptores e, aí, nossa hipótese é de que existe grande influência do ambiente cultural nisso. Sendo assim, entramos no campo cultural da experiência humana que é constituído de uma infinidade de variáveis e será embasado pelas concepções da semântica cultural (SC) de Ferrarezi Jr (2010).

Se, por um lado, podemos perceber uma relação entre corpo (dimensão biológica) e cultura (dimensão extrabiológica) na descrição de Chomsky, adepto do caráter biológico da língua, por outro, percebemos a mesma relação em uma descrição da SC, afeta ao caráter semântico da língua. Segundo Ferrarezi (2013, p. 75)

Trata-se de uma relação indissociável, uma interfluência: nosso pensamento, nossa cultura já estabelecida e a língua que falamos, em que todos os elementos influenciam e alimentam os demais enquanto se retroalimentam $[\ldots]$

Sendo assim, podemos observar uma relação entre esses três elementos (pensamento, cultura e língua).

Até aqui, ressaltamos a relação entre pensamento-cultura-língua. Agora atentamos à ideia de um historiador americano, Donald Kagan, que diz que, se retiradas do homem a razão e a religião a única coisa que lhe resta é a animalidade. A razão e a religião são constituídas de uma natureza semântica, enquanto a animalidade é constituída de uma natureza genética, e é nessa natureza genética que observamos algumas evidências de genes responsáveis (em parte) pelo funcionamento da linguagem, como o FOXP2. Segundo Rocha (2006, p. 122) 


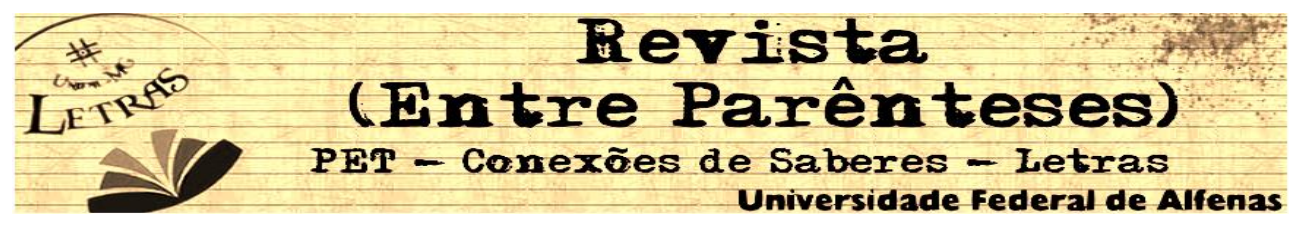

[...] a interpretação mais segura que pode ser feita dessas evidências é a de que o FOXP2 é um dos muitos genes que afetam sistemas ou mecanismos neurais subjacentes à aquisição e ao funcionamento da linguagem - mas que também subjazem a outras funções.

Desta forma, pode-se observar uma ligação entre o que Chomsky chama de "painel de controle", e os genes subjacentes à linguagem. O ponto em comum seria que ambos remetem a uma natureza biológica, mas demandam uma dimensão semântica que os ativa e Ihes dá funcionalidade no âmbito da linguagem. Assim observamos que "A linguagem humana parece estar biologicamente isolada em suas propriedades essenciais [...]." (CHOMSKY, 1998, p. 17), isolamento que é ratificado por Rocha (2006) em seu estudo dos genes.

\begin{abstract}
A análise do padrão de expressão do gene no cérebro, correlacionada às peculiaridades da neuroanatomia $e$ da neurofisiologia desses indivíduos, poderia oferecer uma evidência decisiva sobre a hipótese de que o FOXP2 seria responsável, ao menos em parte, pela organização adequada da circuitaria cerebral necessária para o desenvolvimento normal da fala e da linguagem. (Idem, p. 104)
\end{abstract}

As concepções desses autores, embora abordem aspectos diferentes, parecem evidenciar algo em comum: todas concordam com um caráter multidimensional da linguagem.

Podemos continuar nessa hipótese explorando a ideia de que, se a linguagem tem uma base genética comum em todas as pessoas, acredita-se que todas as línguas apresentem características comuns (universais) fundadas nessa base genética. A relação da linguagem humana com a animal pressupõe algumas semelhanças entre si. Sabe-se que as abelhas "dancam" para indicar a direção de uma fonte de alimento. Segundo Chomsky, (1998, p. 17) "esse sistema [...] possui uma mesma característica da nossa linguagem: a propriedade de referência deslocada, ou seja, nossa capacidade de falar de algo que esteja distante de nós no tempo e espaço".

Mas, além de semelhanças, também existem diferenças. Homens e animais parecem possuir genes específicos para a comunicação. Porém, o sistema humano parece ser bem mais complexo e consciente do que os sistemas animais 


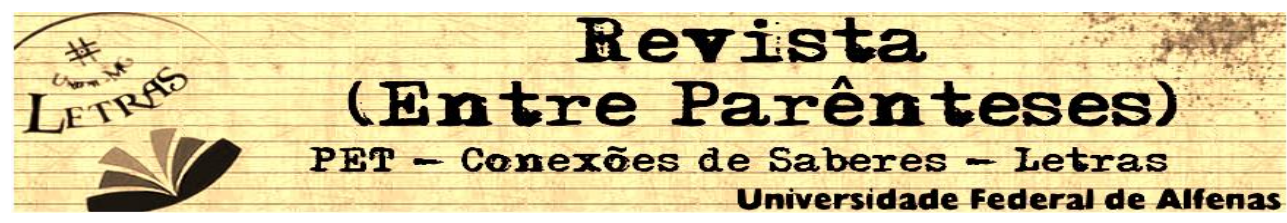

conhecidos, cujo nível de complexidade e de consciência têm se mostrado ativos em escala muito menor do que a humana. Porém, entre essas diferenças nota-se que todas as espécies têm a necessidade de comunicar algo, seja entre seres da mesma espécie, como atrativo de reprodução, por exemplo, seja entre diferentes espécies para um sistema de cooperação, ou simplesmente para a vida social. Além disso, a influência do meio tem sido um fator importante para a multiplicidade de sistemas de comunicação, e como a consciência dos animais é - pelo que sabemos - muito menor do que a nossa, sua comunicação se caracteriza mais como um processo biológico e menos como um processo social (as exceções seriam, pelo pouco que sabemos, mamíferos marinhos e certos símios, como chinpanzés, gorilas e macacos-de-cheiro, por exemplo).

\section{A nomeação como fato linguístico universal}

A dimensão semântica exigiu da espécie humana algo que não se encontra na linguagem animal como a conseguimos entender: a necessidade de nomear categoricamente tudo o que o homem já descobriu a respeito e em seu mundo. Em analogia, um leão e um homem sabem instintivamente que não se deve pular no fogo, mas apenas o homem sentiu a necessidade de dar nome àquele fenômeno que gera um calor intenso bem como a todos os elementos que o integram (combustível, comburente, combustão, energia etc.).

Isso sugere uma ligação entre o instinto e a linguagem, mas acima de tudo, entre a capacidade humana de interpretar semanticamente o mundo e tudo aquilo que o homem ia criando em sua mente a respeito desse mesmo mundo que o cercava. $A$ criação humana em todos os níveis, as interferências do homem sobre o mundo e mesmo o desenvolvimento de sua visão de mundo é o que denominaremos "cultura".

Pensar sobre o mundo e dar nome a coisas acabou gerando uma categorização dos elementos do mundo e, essa categorização, repleta de valores culturais, criou diversas categorias simbólicas, categorias distintas em várias línguas. 


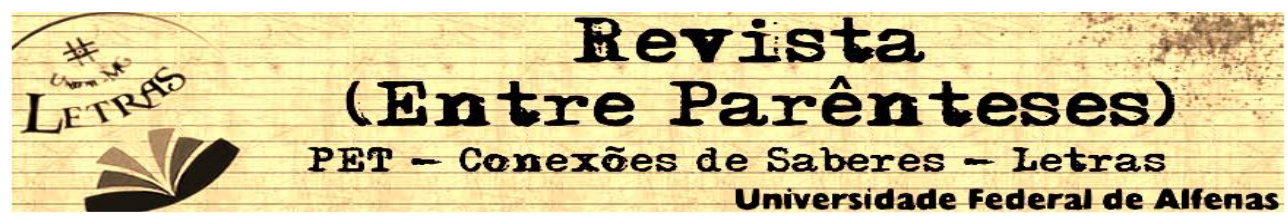

Apesar disso, todas as categorias possuem uma universalidade em comum: todas evitam o caos na linguagem. Estudos linguísticos das últimas décadas, como os da pesquisadora Anna Wierzbicka (por exemplo, Wierzbicka, 1996), nos mostram claramente que a língua atua com base em categorizações do mundo que se refletem, por exemplo, nos parâmetros gramaticais de cada sistema.

Porém, são justamente as peculiaridades gramaticais das línguas (o que Chomsky chamou de parâmetros) que tendem a mascarar essas bases comuns e temos dificuldades para enxergar a universalidade. Se pensarmos na organização estrutural das línguas, de fato perceberemos que não existe caos e desordem. $\mathrm{Na}$ linguagem, ninguém há de negar que até a aparente desorganização linguística de uma conversação informal, por exemplo, é de certa forma organizada. Nada na linguagem é por acaso e ela parece ser um dos sistemas mais perfeitos que existem no mundo. Além de tudo, são sistemas tão complexos e multifuncionais que, até hoje, o homem não foi capaz de esclarecer sua totalidade - apenas nos aproximamos do que ela parece ser. Mas de onde viria toda esssa organização da linguagem?

Podemos imaginar as categorias como um espaço de alocação, a princípio, vago e com suas próprias regras, sobre o conteúdo o qual irá armazenar, como tamanho, formato, função etc. Porém existe uma peculiaridade nessas categorias fixas (fixas durante certo período cronológico até que determinadas nessidades representacionais Ihes obrigem mudanças): uma interdependência entre essas categorias que determinam a estrutura de uma língua e a cultura necessária para que elas se estabeleçam enquanto universalidades capazes de "abrigar" infinitas variáveis.

Devemos ter em mente que a cultura de uma sociedade, que é "[...] toda a construção emanada da mente humana [...]" (FERRAREZI, 2013 p. 74) não poderia ser idêntica à de outra sociedade que possui um ethos diferente, e ambas diferem ainda mais se considerarmos os individualismos. Se a necessidade de nomear as coisas gerou uma universalidade funcional nas línguas (todas as línguas conhecidas nomeiam), devemos considerar que essa mesma universalidade deve ser capaz de abrigar todos os aspectos culturais de uma sociedade, manifestando-os na 


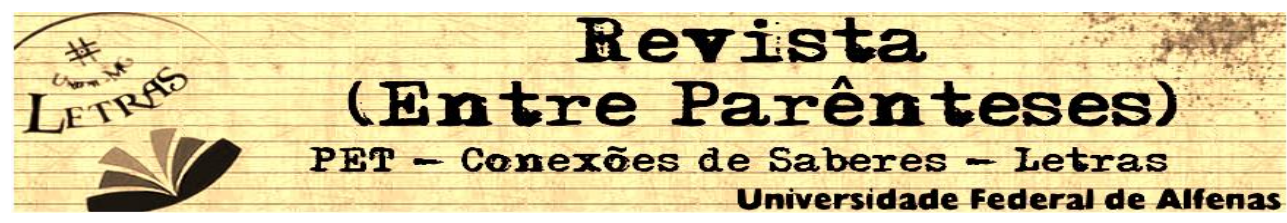

linguagem (o que gera parâmetros gramaticais diferentes, uma vez que cada cultura gera categorias diferentes). Logo, podemos perceber, de início, o quão difícil é uma desvinculação entre os aspectos universais das línguas e as culturas que os concretizam/ manifestam. Essas relações formam um jogo cíclico de forças, dificultando a visualização dos princípios da linguagem.

Hoje, sabemos que as categorias gramaticais do português brasileiro - PB, segundo Ferrarezi (2012) são cinco, e não dez. Poderíamos nos perguntar se em outras línguas essas categorias, que são de caráter representacional, são as mesmas. A resposta que encontraríamos, sem muito esforço, seria um "não". Isso se dá pelo fato de que a visão de mundo de outras sociedades pode abrigar conceitos que outras culturas não tem. Por exemplo, a categoria gramatical usada para representar o espírito/essência das coisas vivas usada em Yanomami, categoria que o PB desconhece. Percebemos, com isso, que a necessidade de nomear o mundo gera, na verdade, um universal de procedimento de categorização nas línguas (todas as línguas categorizam, todas as línguas nomeiam), porém com parâmetros diferentes. Isso possibilita que as variáveis humanas culturais e as necessidades expressivas se ajustem em um sistema linguistico aberto.

A coerência da linguagem pode também estar nos traços que definem uma categoria. Por exemplo a categoria dos nomes (substantivos, na tradição) assim como as outras categorias é quem ditam as regras para as palavras estarem inseridas nela, e não o contrário. Um verbo ou uma preposição podem, por exemplo, aparecer com a função de nome em uma sentença. Essa flutuação das palavras nas categorias mais rígidas exibe que não pode existir comunicação efetiva sem uma estrutura cultural de base que sustenta a estrutura gramatical, que, por sua vez, provavelmente esteja vinculada a aspectos genéticos humanos (ou seja, as línguas são como são porque nossa estrutura genética só assim o permite). Temos, então, um intrincado sistema de influências: uma base genética determina padrões possíveis que são preenchidos por categorias culturais que geram uma gramática que funciona delimitada pelas bases genéticas. Algo que podemos representar, grosseiramente, assim: 

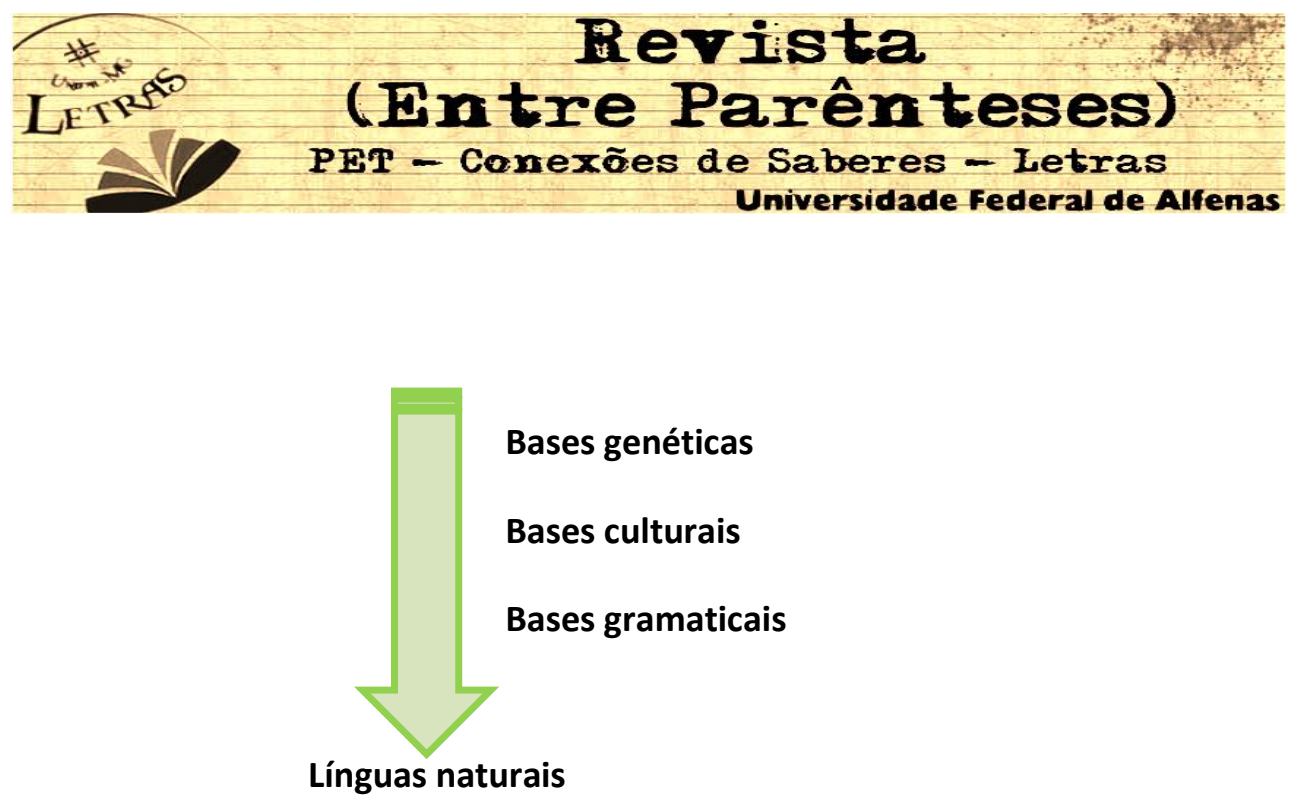

\section{A dimensão semântica: ainda por compreender integralmente}

Em termos gerais, os estudos linguísticos se concentram na superficialidade das línguas. A dimensão mais profunda, a dimensão semântica, por exemplo, é normalmente desprezada na maioria dos estudos ou tratada de forma muito superficial e insatisfatória. Já vimos que a estrutura gramatical de uma língua é, em grande parte, determinada pela cultura à qual essa língua pertence. Seguindo nessa perspectiva e lembrando de que a cultura é resultante do pensamento, não podemos nos esquecer de que o pensamento humano não é tão simples e padronizado de pessoa para pessoa. Devemos sempre considerar as variáveis humanas nos estudos linguísticos já que, elas são de vital importância para a compreensão de padrões linguísticos mais sistêmicos.

Entrando nesse ambiente do pensamento humano, inevitavelmente, entramos no ambiente semântico que, se desconsiderado, torna inviável diagnósticos completos sobre a linguagem. Normalmente, por causa de alguma "força mística" da tradição normativa, que parece exercer grande influência ainda hoje nos estudos sobre linguagem, a dimensão semântica passa desapercebida muitas vezes. Isso não se limita em um reducionismo da linguagem, se expande para o sistema educacional gerando consequências catastróficas. Esse reducionismo que não considera a semântica pode ser percebido nos livros didáticos. Segundo Marcuschi (2001, p. 47) 


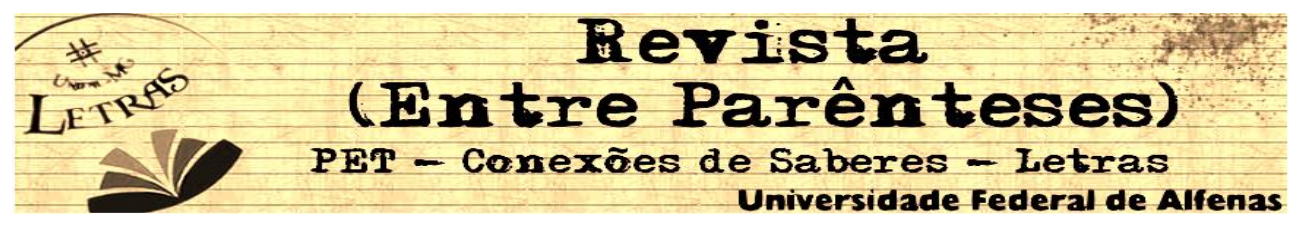

De uma maneira geral, a língua é tomada como um instrumento de comunicação não problemático e capaz de funcionar com transparência e homogeneidade. A dar crédito aos LDP, a língua é clara, uniforme, desvinculada dos usuários, descolada da realidade, semanticamente autônoma e a-histórica. Uma espécie de ser autônomo e desencarnado.

Em relação à realidade dos falantes nota-se algo: Se por um lado o homem cria noções individuais, por outro, existem noções coletivas que parecem ajudar na definição das noções individuais. Seriam realidades que abrigam uma natureza semântica consensual entre os indivíduos: o que chamaremos aqui simplesmente de sentidos.

Considerando a língua como objeto representativo do mundo, notamos que todos os níveis linguísticos só podem operar com base em duas dimensões distintas: 1. a da função que o objeto linguístico desempenha no sistema, e; 2. a do sentido que pode a ele ser atribuído para que tal objeto linguístico adquira seu caráter representativo. As funções como vimos acima podem ser diversas devido à flutuação das palavras nas categorias gramaticais. Mas, os sentidos não são tão simples de serem definidos. Imaginemos uma sentença simples do PB como: "João é um cachorro". Agora, poderíamos nos perguntar: qual é o sentido da palavra "cachorro" nesta sentença? Normalmente, as pessoas responderiam que o sentido costumeiro da palavra "cachorro" corresponde ao objeto referencial, no caso um animal. Mas, nem isso é tão simples. Há um sem-número de outros objetos do mundo chamados de "cachorro", desde bibelôs e cerâmica até peças de máquinas. Uma sentença tanto escrita ou oral nunca "flutua solta no espaço", pois tudo o que dizemos ou escrevemos não surge do acaso e existe uma relação entre as palavras e o que as antecede ou precede no nível linguístico. É o que chamamos de contexto. O contexto apresenta informações essenciais para a compreensão do sentido de cada palavra.

A palavra "cachorro", dentro de uma estrutura solta como a acima, "descolada da realidade" (na concepção de Marcuschi), normalmente vai ter um sentido costumeiro, em uso com mais frequência por uma comunidade. Mas, já sabemos, hoje em dia, que sentenças soltas só existem na cabeça dos gramáticos 


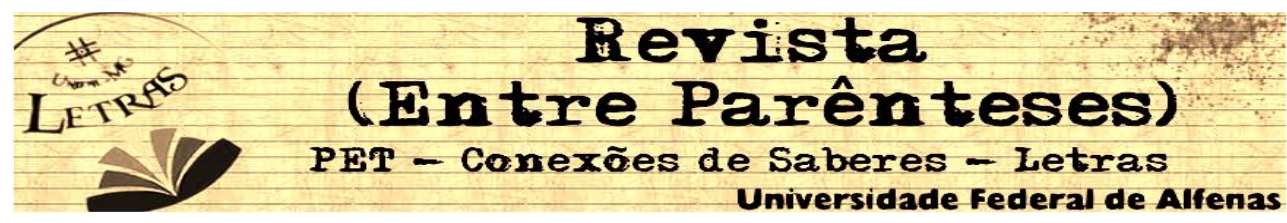

tradicionalistas, e que qualquer palavra quando pronunciada ou escrita estará vinculada a um contexto, contexto que segundo Ferrarezi $(2010$, p. 116, 117)

[...] é que vem antes e depois do sinal-palavra, o restante do texto, o texto que precede e o que sucede o próprio texto, o texto que se junta e que referencia o texto, num entrelaçar de palavras em textos que acabam formando o complexíssimo conjunto de sinais interligados que procuramos entender quando nos comunicamos.

Sendo assim, dentro de contextos diferentes, é possível que a palavra "cachorro" adquira sentidos completamente diferentes do costumeiro. E indo mais além, podemos dizer que o ambiente extralinguístico também interfere na especialização dos sentidos dentro de um contexto, pois todo contexto se insere em um ambiente enunciativo, mesmo os contextos escritos. Esse ambiente é o cenário. Segundo Ferrarezi (2010, p. 120)

[...] o cenário compreende todos os fatores relevantes do ponto de vista dos interlocutores para a especialização dos sentidos dos sinais. Esses fatores incluem todo o complexo conjunto situacional que envolve a enunciação, desde as roupas de quem enuncia (isso é relevante, por exemplo, num ato de pedido de namoro) até elementos fortuitos que se relacionem de qualquer forma ao que se enunciou (como um avião que passa por sobre os falantes na hora da enunciação, se, de qualquer forma, esse fato interferir no processo de especialização).

Logo, uma palavra com o sentido preliminarmente definido dentro de um contexto, pode ganhar um sentido completamente diferente em um cenário diferente (por exemplo, na mesma sentença citada, "cachorro" pode ser um animal, se imaginarmos uma pessoa que dá "nome de gente" aos seus cachorros, ou pode ser um homem sem caráter, em outra situação)

Todas essas características de sentido que o homem atribui ao mundo são fundamentais para a compreensão da linguagem, envolvem todas as características do homem enquanto ser racional, e fazem parte de sistemas lógicos e abertos ao mesmo tempo. Mais do que isso, a forma de construir sentidos e atribuí-los às palavras parece ser universal nas línguas naturais. Negar a natureza semântica de uma língua é como negar a própria língua enquanto objeto de estudo, disso resultaria contradições, já que "[...] o que os sentidos veiculam dá à mente "uma 


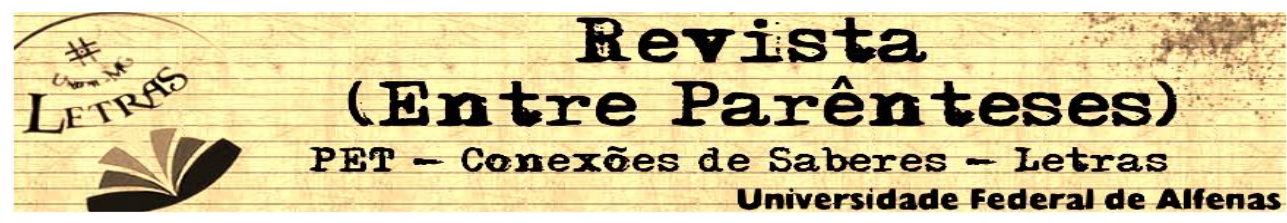

ocasião de exercitar sua própria atividade" para construir "ideias inteligíveis e concepções de coisas a partir dela própria" [...]" (CHOMSKY, 1998, p 35). Pensar na natureza semântica de uma língua é como pensar em sua energia vital, e essa energia vital parece estar vinculada diretamente a princípios universais, como dar nome às coisas.

\section{Princípios, parâmetros e uma gramática universal}

Se conseguíssemos identificar com clareza quais são os princípios universais por trás dos parâmetros gramaticais, talvez tivéssemos condições de construir uma "gramática universal que permitisse compreender o funcionamento básico e os desdobramentos peculiares de todos os sistemas gramaticais. Tal pretensão já existe há muito tempo. Os americanos são os que mais investem nesse tipo de estudos. Veja-se, por exemplo, o Google Tradutor, o mais eficaz do mundo, que sem um conhecimento conjunto por parte de linguistas e programadores sobre universalidades e variáveis linguísticas jamais chegaria ao nível em que está. Não apenas tradutores, mas também sistemas de reconhecimento de voz dependem de um amplo conhecimento sobre a linguagem para serem desenvolvidos.

Os tradutores, por mais eficazes que sejam, até hoje não foram capazes de chegar à perfeição, (e esperamos que jamais cheguem, pois as consequências poderiam ser catastróficas para a humanidade). $O$ fato de eles não serem perfeitos reside na lógica de que nenhuma máquina do mundo é capaz de abrigar todas as variáveis humanas, inclusive as culturais, em tempo real, e sabemos perfeitamente que as línguas são mutáveis. Além disso, seria necessária uma compreensão completa dos aspectos genéticos da linguagem e de como eles são ativados pelos estímulos da cultura, para se chegar aos princípios universais plenos. Se, por um lado, mostramos a importância que o ambiente semântico tem para a compreensão da linguagem, agora, também, ressaltamos a mesma importância para a gênese da linguagem. Desprezá-la também implicaria em um reducionismo da linguagem enquanto objeto complexo. 


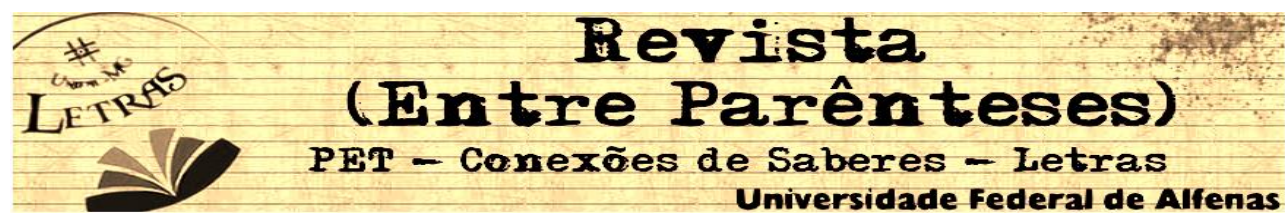

Diversos estudos nos apresentam aparentes evidências de que a linguagem não pertence apenas a um ambiente representacional, fazendo parte ao mesmo tempo de um ambiente biológico. Caso contrário, doenças como dislexia, afasia e epilepsia, que são causadas por deficiências em determinados genes ou da massa encefálica e não no aparelho fonador, não seriam capazes de afetar o uso da linguagem. Tais evidências parecem caminhar ao encontro das concepções de Chomsky em relação à aquisição da linguagem. Segundo Chomsky (1998, p. 39, 40)

[...] a abordagem de Princípios e Parâmetros, que se baseia na ideia de que o estado inicial da faculdade de linguagem consiste em princípios invariantes e em um leque finito de escolhas quanto ao funcionamento do sistema inteiro. Uma língua em particular é determinada fazendo-se essas escolhas de um modo específico.

Se existem mesmo tais princípios invariantes vinculados a genes responsáveis pela linguagem, então, a nomeação das coisas, universal em todas as culturas atualmente conhecidas, seria um desses princípios que atestam uma relação corpo-cultura. Já os parâmetros se explicam aparentemente pela cultura que uma comunidade de pessoas cria para representar seus mundos. Percebe-se assim, uma intricada relação que vai desde aspectos genéticos até um amplo sistema semântico. A dificuldade em se identificar os princípios universais da linguagem, não reside na ideia de identificar todos os genes responsáveis pela linguagem e sim em compreender com clareza como e porque eles surgiram, e para além disso, o que Ihes dá funcionalidade, já que a linguagem não é apenas genética, mas principalmente abstração de realidades concretas e metafísicas.

Se os parâmetros da linguagem são "produtos" culturalmente definidos, então os princípios da linguagem residem na animalidade do homem, e como agora estamos falando de características de uma espécie, naturalmente não encontraremos muitas variáveis como se encontra no ambiente cultural, o que segundo Rocha (2006, p. 63)

[...] não significa que os genes não tenham um papel fundamental no desenvolvimento dessas habilidades. Múltiplos genes parecem estar envolvidos na organização de estruturas neurais complexas que antecedem 


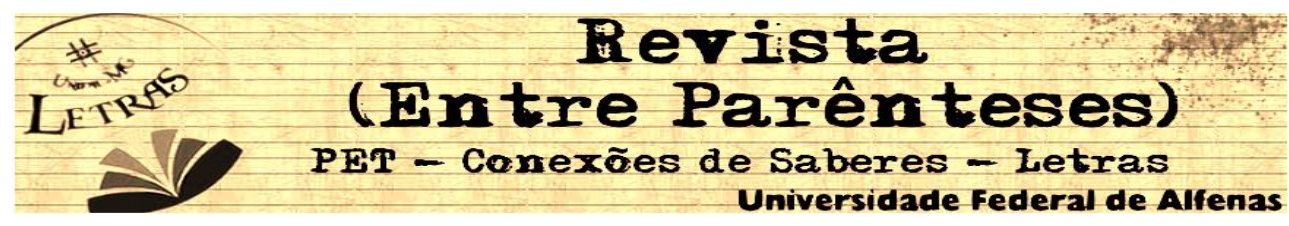

e tornam possível o desenvolvimento de habilidades cognitivas complexas, como a linguagem.

O único gene até hoje descrito como "gene da linguagem", o FOXP2, não está restrito apenas ao tecido cerebral como aponta Rocha, mas ele é encontrado em outros órgãos como o coração por exemplo. Isso mostra claramente (até onde se sabe) que não existem genes dedicados unicamente ao desenvolvimento da linguagem. Mas, que de certa maneira são responsáveis por regular um padrão universal nas línguas, já que, o instinto parece anteceder a criação de qualquer racionalidade.

Diversos estudos foram feitos ao longo de anos em uma família que apresentava mutações no gene FOXP2. Alguns membros da família apresentavam diversas dificuldades em relação à linguagem, não decorrentes de problemas de articulação. E o que se descobriu segundo Rocha, (2006, p. 73) é que:

[...] fica claro que a dificuldade com a linguagem na família KE não se
limita a problemas articulatórios. Assim, Hurst et al. observam uma demora
significativa em atividades de nomeação de objetos comuns (acesso
lexical), acompanhada por uma tendência ao "uso de palavras
aproximadas", como glass ou tea para cup e sky para star. Os autores
relatam ainda a não-espontaneidade da fala, com as crianças
mostrando-se relutantes em conversar (sic). Embora tenham enfatizado os
déficits expressivos, os autores observaram também dificuldades na
compreensão da linguagem, notadamente com frases comparativas e
passivas [...]

Com esse estudo da família KE observa-se que o ambiente extrabiológico da linguagem não se limita em sí, caso contrário uma deficiência genética não seria capaz de interferir na compreensão. O que se tem aqui ainda é uma "obscura" relação entre genes e semântica, um jogo cíclico como dito no início deste trabalho, e não planos linguísticos operando separadamente.

Porém, como há uma relação direta entre a cultura (que ativa os interruptores chomskyanos) e a parte genética, é somente nessa inter-relação de concepções que podemos enxergar alguma lógica na universalidade linguística, como a nomeação das coisas do mundo, a construção de analogias e a predicação, comuns em qualquer língua atualmente conhecida. 


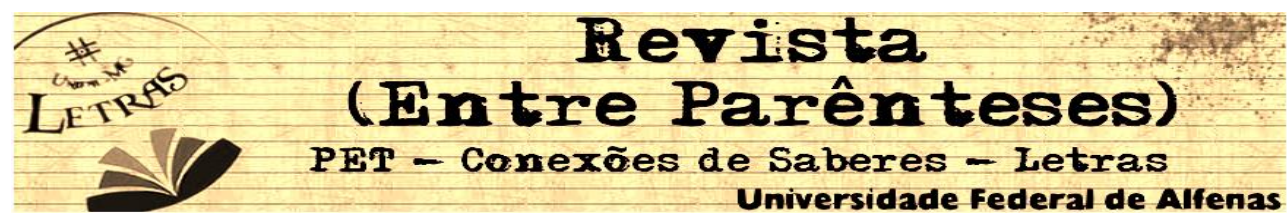

Então, estudos que busquem identificar traços universais, precisam passar pelas peculiaridades culturais, pelas relações entre o homem e seu ambiente e pelas características gramaticais dos sistemas linguísticos, pois esse é o material de que dispomos para análise, e não outro.

\section{Considerações finais}

Definir uma língua se torna extremamente dificil a medida em que são evidenciadas suas características inter-relacionais. A universalidade linguística, que ganha funcionalidade no campo semântico, parece ser inevitável tanto para a organização das línguas naturais, quanto para a própria sobrevivência humana. A necessidade de nomear as coisas do mundo nos diz muito a respeito da linguagem humana: todas as culturas conhecidas desenvolveram um amplo sistema de categorizações e representações ideológico-interpretativas de seus mundos. Isso significa que, para dar conta desse amplo sistema de abstrações interpretativas do mundo, o homem precisou criar um sistema de categorias tão complexo que dificilmente pode ser manipulado pela vontade.

Se todas as linguas conhecidas nomeiam e têm uma estrutura gramatical correspondente a essas nomeações é porque existe um princípio universal ligado a esse aspecto e que rege essas línguas. Isso parece se tornar cada vez mais lógico com evidências nas teorias e dados de diferentes áreas e autores que, por mais diferentes que sejam, tendem a se encontrar no mesmo caráter multidirecional da linguagem que atesta relações entre a genética humana e a cultura do homem. Porém, essas relações ainda são obscuras para a ciência e, assim, não nos estranha que ela ainda não tenha descoberto a cura definitiva para doenças que afetam o uso e a compreensão da linguagem.

É certo que a linguagem não é apenas antropológica e não depende somente da cultura para se estabelecer. Antes, necessita de bases genéticas sobre as quais se desenvolve. Se fossem produtos unicamente culturais, as línguas naturais não seriam capazes de se sustentar. Também vale ressaltar o fato de que

Revista (Entre Parênteses) - ISSN 2238-4502

Volume 1, Número 5, 2015 


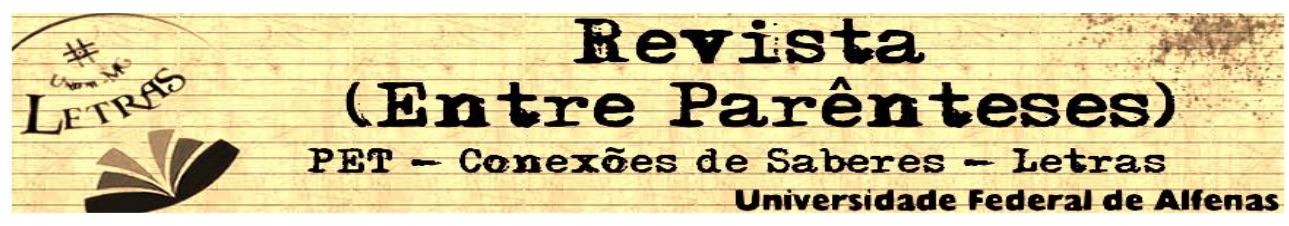

elas dependem de um sistema neurológico que se inter-relaciona com a cultura e, além do mais, todo o processo de evolução das línguas, o que inclui a formação dos sons, o desenvolvimento morfológico, a organização sintática e semântica, e a maneira como esses sistemas se adequaram estruturalmente, dentro de uma perspectiva diacrônica, parece ter sido um "planejamento" complexo demais, que exigiria algo além da sociabilidade humana para se concretizar.

Os estudos sobre os genes da linguagem ainda são poucos, mas a evidência de que a deficiência no gene FOXP2 em alguns mesmbros da família KE pode afetar a capacidade de compreensão linguística já é um grande avanço para a constatação da interdependência da cultura com a genética.

\section{Referências:}

CHOMSKY, N. Novos Horizontes no Estudo da Linguagem e da Mente. São Paulo: Editora da UNESP e Cambridge University Press. 2005.

Arquitetura da Linguagem. Tradução de Alexandre Morales e Rafael Ferreira Coelho. Bauru: Edusc, 2008.

FERRAREZI Jr., Celso. Introdução à Semântica de Contextos e Cenários: de la langue à la vie. Campinas, SP: Mercado de Letras, 2010.

. Semântica, semânticas: uma introdução. (Org.) Celso Ferrarezi Junior e Renato Basso. São Paulo: Contexto, 2013.

Cultural, 2012

Qual é o problema das gramáticas normativas? 1 ed. Santos: Artefato

GONÇALVES, R. R. F. A Expressão do FoxP2: Uma introdução ao estudo das relações entre genes e linguagem. 128f. Dissertação (Mestrado em Linguística) Universidade Federal do Rio Grande do Sul, Porto Alegre. 2006

KAGAN, D. Introduction to Ancient Greek History. Yale University: Open Yale Courses. Disponível em:< http://oyc.yale.edu/classics/introduction-to-ancient-greekhistory/>. Acesso em: 05 out. 2014. 


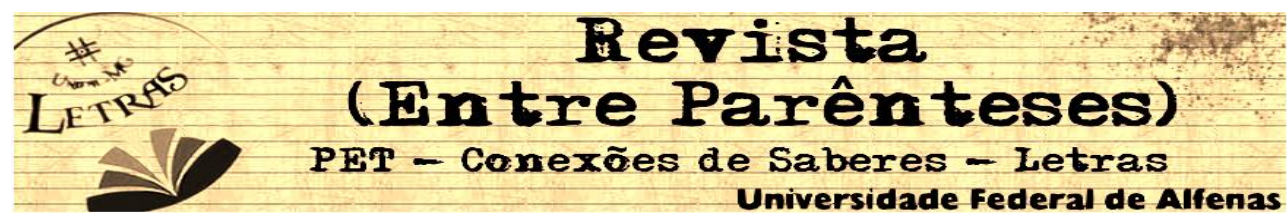

MARCUSCHI, L. A. Compreensão de Texto: Algumas reflexões. In: DIONÍSIO, Ângela P.; BEZERRA, M. Auxiliadora (Org.). O livro didático de Português: Múltiplos olhares. Rio de Janeiro: Editora Lucerna, 2001, p. 46-59.

SACKS, O. A Mente Assombrada. Tradução de Laura Teixeira Motta. 1 ed. São Paulo: Companhia das Letras, 2013. 